\title{
好酸球性副鼻腔炎と前頭洞病変
}

\author{
竹野 幸夫 $^{1}$ ， 久保田和法 ${ }^{1}$ \\ ${ }^{1}$ 広島大学大学院医歯薬保健学研究院耳鼻咽喉科・頭頸部外科
}

\section{Frontal sinus disease in eosinophilic chronic rhinosinusitis}

\author{
Sachio Takeno ${ }^{1}$, Kazunori Kubota ${ }^{1}$ \\ ${ }^{1}$ Department of Otolaryngology, Head and Neck Surgery, Division of Clinical Medical Science, Programs for Applied Biomedicine, \\ Graduate School of Biomedical Sciences, Hiroshima University
}

キーワード：好酸球性副鼻腔炎, 前頭陥凹蜂巣, 前頭洞炎, 内視鏡下副鼻腔手術

Key words: eosinophilic chronic rhinosinusitis, frontal recess cell, frontal sinusitis, endoscopic sinus surgery

\section{はじめに}

ヒト副鼻腔はそれぞれが狭い排泄換気路（自然口）に よって固有鼻腔と連続しているが，その中でも前頭洞は排 泄路である前頭陥凹（frontal recess）の解剖学特殊性によ り多彩な個体差が生じやすい副鼻腔である。このため前頭 洞排泄路の位置は前頭陥凹蜂巣の発育に影響を受け，かつ 排泄路が正常症例においても 1-2 mm 程度の矮小な粘膜間 隙でしかないため, 内視鏡下副鼻腔手術（ESS）において も，前頭洞開放は技術的難易度が高いとされている。

一方で新たな慢性副鼻腔炎の病態分類である好酸球性副 鼻腔炎に関しては, 平成 22 年より「好酸球性副鼻腔炎の 疫学, 診断基準作成等に関する研究」（研究代表者：藤枝 重治）が立ち上がり，昨年には診断に使用する臨床スコア も提唱され ${ }^{1)}$, さらには本年 7 月より厚労省の難病指定疾 患にもなり, 病態の解明と臨床概念の周知化が急速に進ん でいる。好酸球性副鼻腔炎に関しては,「両側性であり CT 画像所見で上顎洞よりも篩骨洞の陰影が優位である」点 が，臨床的に重要な指標とされている。一方で前頭洞に関 しては上記の解剖学的特殊性もあり，いまだ罹患状況に関 して確立した報告がないのが現状である。以下に興味を引

2015 年 7 月 29 日受稿

別冊請求先：竹野幸夫

干734-8551 広島市南区霞 1-2-3

広島大学医学部耳鼻咽喉科

TEL: 082-257-5252, FAX: 082-257-5254

E-mail: takeno@hiroshima-u.ac.jp
く症例を提示して, 本稿のテーマである「好酸球性副鼻腔 炎と前頭洞病変」に関して当科のデータを交えつつ概説し たいと思う。

\section{症例}

70 歳代，男性。

主訴：前頭部痛。

臨床経過と検査所見：潜水（素潜り）が趣味で瀬戸内海 近郊で行っていた。2 年前くらいから海にもぐるときに, 両側の前頭部に激しい痛みが生じるようになり，支障を生 じるようになったため当科紹介受診。血液所見は好酸球 比率 8.5\%, アレルギー検査ではダ二抗原陽性。副鼻腔 CT では両側性の前頭陥凹領域の陰影所見と篩骨洞の粘膜肥 厚像を認めた。また前頭陥凹蜂巣の分類として, 右側は agger nasi cell (ANC), frontal cell type 1 (T1), interfrontal sinus septal cell (IFSSC) を, 左側は ANC, T2 cell, frontal bullar cell (FBC) を認めた（図 1a, b)。好酸球性副鼻腔炎（JESREC 診断基準項目スコア 13 点）に伴う前頭洞病変と診断。反 復する放散痛 (sinus referred pain) の加療目的にて, 内視 鏡下副鼻腔手術を施行した。手術により上記の前頭陥凹蜂 巣を開放し，前頭洞への排泄路を拡大した（図 1c，d）。術 後経過は良好で, 潜水時に誘発されていた前頭部痛は消失 した。 

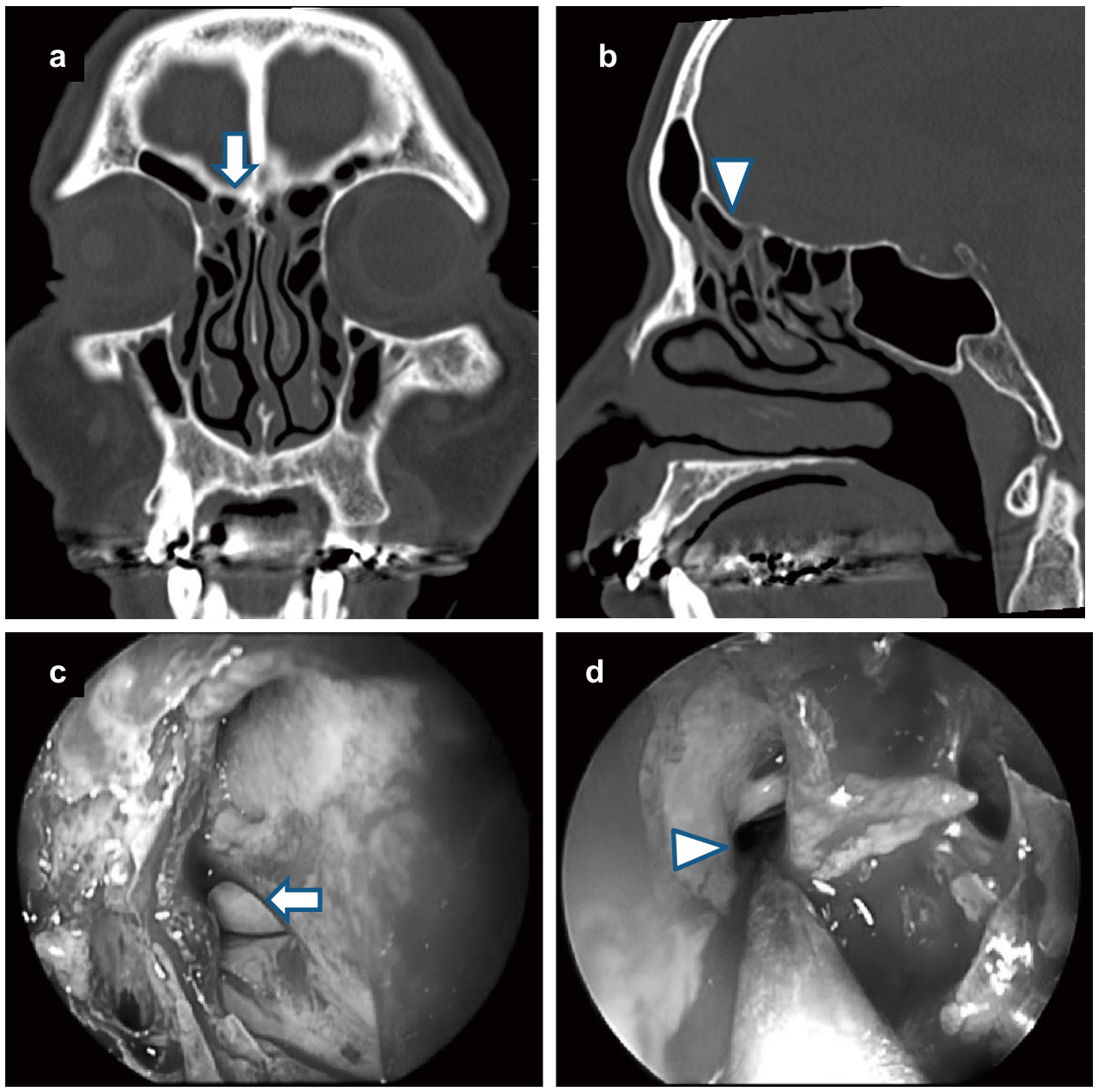

図 1 症例の CT 画像 $(\mathrm{a}, \mathrm{b})$ 並びに手術時の内視鏡所見 $(\mathrm{c}, \mathrm{d})$ 。右鼻腔に排泄路を有する interfrontal sinus septal cell (IFSSC, 矢印) と, 左側 には前頭洞内にまで発育する frontal bullar cell (FBC, 矢頭) が認められ，反復する頭痛の原因と考えられた。

\section{前頭陥凹の解剖}

前頭洞排泄路（鼻前頭管）が中鼻道に開口することは， これまでの教科書にも記載されており古くからよく知られ た事実である。しかし，詳細にみると個々人の前頭洞排泄 路はバリエーションに富み, 鼻前頭「管」というよりはむ しろ前頭陥凹（前頭窩）に扔ける蜂巣と蜂巣の「隙間」と とらえる方が適切である。最近の鼻副鼻腔 CT 検査におい ては, $0.5-1 \mathrm{~mm} の$ thin sliceで従来の水平断・冠状断に加 えて矢状断を再構成することで前頭洞排泄路が存在する前 頭陥凹を細かく検討することができるようになった。Lee と Kuhn ら ${ }^{2)}$ は一見複雑に入り組んでいるように見える前 頭陥凹蜂巣をその位置とサイズによって分類し理解を進め た。この分類は鼻科医の共通言語として学会などを通じて 膾多してきているといえる。具体的には，前頭陥凹前方に 位置する agger nasi cell と frontal cell type 1-4, 後方に位置 する suprabullar cell, frontal bullar cell, supraorbital ethmoid cell, 内側に位置する interfrontal sinus septal cell などである（表 1)。これら前頭陥凹蜂巣の分布に関しては人種により一定
の傾向を示し、アジア系人種間で類似し，白人とアジア系 では相違があると報告されている3)。

\section{前頭洞病変に対する ESS}

Wormald の提唱する building block conceptでは先述の 前頭陥凹蜂巣 1 つ 1 つをブロックに見立てて積み重ね, 前 頭洞排泄路が積み重ねたブロック（蜂巣）の前後・内外の どこを通るのかを 3 次元的に同定する。手術では排泄路に そって自分が現在操作している蜂巣を正確に把握しながら 後方から前方へ, 内側から外側へ順序良く隔壁を除去して いき排泄路を拡大・開放していく。しかしながら，好酸球 性副鼻腔炎で鼻内に鼻茸が充満している重症例や再手術症 例，あるいはT3や T4 cell が存在する場合などでは，型通 りの蜂巣の把握が困難な場合もある。そこで本邦で提唱さ れてきている概念として area managementがある5)。前頭洞 手術に扮ける解剖学的危険部位は前頭蓋底, 眼窩, 前篩骨 動脈（管）である。あらかじめこれらの構造物を内視鏡下 に同定し，その内側にある「安全な area」で鉗子操作を進 
表 1 各人種における前頭陥凹蜂巣の存在頻度。ANC は最もよく見られる前頭陥凹蜂巣である。白人はSOECの頻 度がアジア人に比較して高く, SBCはその逆の分布を示す。

\begin{tabular}{|c|c|c|c|c|c|c|c|c|c|c|}
\hline 蜂巣種類 & \multicolumn{2}{|c|}{$\begin{array}{c}\text { 日本人； } \\
300 \text { 側, No. }(\%)\end{array}$} & \multicolumn{2}{|c|}{$\begin{array}{c}\text { 台湾人； } \\
363 \text { 側, No. }(\%)\end{array}$} & \multicolumn{2}{|c|}{ 中国人, } & \multicolumn{2}{|c|}{$\begin{array}{c}\text { 韓国人, } \\
114 \text { 側. No. }(\%)\end{array}$} & \multicolumn{2}{|c|}{$\begin{array}{c}\text { 白人, } \\
82 \text { 側, No. }(\%)\end{array}$} \\
\hline ANC & 265 & $(88.0)$ & 323 & $(89.0)$ & 380 & $(94.1)$ & 107 & $(94.0)$ & 71 & $(86.6)$ \\
\hline $\mathrm{FC} 1$ & 111 & $(37.0)$ & 78 & $(21.5)$ & 98 & $(24.4)$ & 26 & (22.8) & 29 & $(35.4)$ \\
\hline $\mathrm{FC} 2$ & 19 & $(6.3)$ & 38 & $(10.5)$ & 28 & $(7.0)$ & 16 & $(14.0)$ & 17 & $(20.7)$ \\
\hline $\mathrm{FC} 3$ & 13 & (4.3) & 28 & (7.7) & 33 & $(8.2)$ & 9 & (7.9) & 7 & $(8.5)$ \\
\hline $\mathrm{FC} 4$ & 4 & (1.3) & 0 & (0) & 0 & (0) & 0 & (0) & 0 & $(0)$ \\
\hline $\mathrm{SBC}$ & 111 & $(37.0)$ & 142 & (39.1) & 148 & $(36.6)$ & 45 & $(39.5)$ & 9 & $(11.0)$ \\
\hline SOEC & 18 & $(6.0)$ & 28 & (7.7) & 22 & (5.4) & 3 & (2.6) & 53 & $(64.6)$ \\
\hline FBC & 21 & (7.0) & 23 & (6.3) & 36 & $(9.0)$ & 16 & $(14.0)$ & 5 & $(6.1)$ \\
\hline IFSSC & 26 & (8.6) & 35 & $(9.6)$ & 25 & (12.4) & 10 & $(8.8)$ & 6 & $(7.3)$ \\
\hline
\end{tabular}

文献 3 をもとに改変。

めることで，合併症を回避しかつ確実に蜂巣隔壁を除去す るというコンセプトである。

\section{好酸球性副鼻腔炎における前頭洞病変の臨床的特徵}

好酸球性副鼻腔炎は粘膜自体が病的状態に陥りやすいた めに尚，好酸球性炎症自体，あるいは術後性や外傷性によ る前頭洞炎頻度が高くなることは理論的に予測可能である ものの, 実際に対照群を設けて前向きに比較検討したエビ

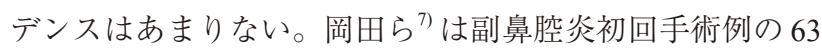
例について, ESS 施行後の前頭洞の開存度を内視鏡下に評 価している。その結果, 喘息合併の有無による開存率を比 較したところ，喘息非合併例で $97.3 \%$ ，喘息合併例で $66.7 \%$ と有意に後者で閉塞例が多かったと報告している。また大 櫛らは慢性副鼻腔炎症例 136 例を対象にして, ESS 術後の 病状再発に寄与する因子の解析を行っている ${ }^{8)}$ 。その結果, 末梢血好酸球増加 ( $9.5 \%$ 以上), 喘息の合併, 前回の手術 に扔ける未開放の笠骨蜂巣スコアの各因子が予後不良に統 計学的に寄与していたと報告している。さらに, 前頭洞に 沶ける術後経過不良例に絞って検討したところ，骨隔壁が 残存していた篩骨蜂巣の中でも, 前頭陥凹周囲の含気腔で ある ANC, SBC，SBCなどを含む上前方領域に扔ける不完 全な手術操作の影響が，他の上下方領域や後方領域（後節 骨洞）に比較して大きかったと述べている。このような前 頭陥凹周囲の蜂巣の遺残は, 理論的に好酸球性ムチンなど の炎症惹起物質の貯留延滞を引き起こし, 炎症の遷延化や 鼻茸再発の要因となることが推定される。

一方外国に扔ける報告では，気管支喘息患者 135 例を対 象として, CT 画像検査にて副鼻腔炎の有無と罹患洞の傾 向を比較したものがある9”。その結果，気管支喘息患者で は対照群に比較して, 粘膜の病的変化と陰影スコアが有意 に高值であった。また気管支喘息症例でも，末梢血好酸球 （\%）が高いものほど陰影スコアが重症であったものの, 総 IgE 值には影響を受けなかったとしている。さらに興味
深いことに，副鼻腔各洞の罹患程度の比較では，軽症喘息 群では笠骨洞と OMC 領域 (ostiomeatal complexes) に扔け る陰影が高度であったのに対して, 重症喘息群では上顎 洞, 前頭洞，そして蝶形骨洞の陰影が高度であったと述べ ている。

\section{内視鏡下副鼻腔手術の役割について}

好酸球性副鼻腔炎症例に招ける手術手技に関しては, $\mathrm{OMC}$ 閉塞部位の解除, 鼻茸切除や単洞手術, あるいは balloon sinuplastyなどのいわゆる低侵襲な手法は疾患の長 期予後の改善に寄与しないと考えられている。副鼻腔各洞 の隔壁を可及的に取り除き，全体を単一腔（a neosinus） として再構築することにより, 炎症性物質の停滞を防ぎ, かつステロイド製戍などのアドヒアランスの向上に努める ことが重要であるとされている。これに関連して Snidvongs らは, 副鼻腔粘膜へ高度な好酸球浸潤 (10 個/HPF 以上) を組織学的に認めた 41 例を対象に, その CT 画像を解析 している ${ }^{10)}$ 。その結果これらの症例では, 前頭洞の陰影程 度と OMC 閉塞との間には, 有意な関連性を認めなかった と述べている。そして本領域の排泄路の障害が, 好酸球浸 潤を伴う副鼻腔炎の発症機序に寄与する役割について否定 的な見解を示している。一方で, 161 例 294 側について内 視鏡下前頭洞手術後の開存性を平均 46 ケ月にわたって評 価したChan らの報告では，内視鏡所見が良好例の割合は ECRS 症例 (58 例) で $85 \%$ であるのに対してnon-ECRS (103 例)では $90 \%$ となり, 統計学的に有意差は認めてい ない"1)。同時に自覚鼻症状のスコア (SNOT-20) の改善程 度の両群間で差異を認めなかったとしており, 結論として ESS はずいずれの群に対しても有効な手術法であると述べ ている。

近年, 拡大前頭洞手術と呼ばれる Draf type III (endoscopic modified Lothrop procedure: EMLP）の適応についての報告 も散見される。すなわち, 好酸球性副鼻腔炎など術後鼻茸 
再発の危険性が高い副鼻腔炎症例では, 前頭洞に関しても あらかじめ広いドレナージルートを形成する目的で初回手 術から本術式が選択されるべきとの意見もある。Wormald らは喘息もしくはアスピリン不耐症合併の鼻ポリープ症患 者では長期成績の改善, 再手術のリスク減少のため Draf type III drillout 法が有効であったと述べている ${ }^{12}$ 。

\section{前頭洞粘膜における好酸球浸潤の機序}

今回述べたように，好酸球性副鼻腔炎患者における前頭 洞並びに前頭陥凹蜂巣の陰影スコアは，化膿性副鼻腔炎 （非好酸球性）に比へ，重症化しやすいことが考えられる。 その機序としては当然のことながら，解剖学的な換気排泄 障害以外にも局所サイトカインによるバイアスを受けて いる可能性が想定される。実際，我々の鼻副鼻腔粘膜にお ける好酸球関連サイトカインの発現を検討した結果でも, 好酸球性副鼻腔炎症例の前頭陥凹は篩骨洞粘膜と類似の profile を呈し, IL-5 な゙の発現立進が観察されている ${ }^{13)}$ 。 また好酸球性副鼻腔炎と類似の症状・所見を呈し, しばし ば鑑別を要するアレルギー性真菌性鼻副鼻腔炎（allergic fungal rhinosinusitis, AFRS) は, 副鼻腔組織内に著明な好 酸球浸潤を認めると同時に, 症例により副鼻腔を構成する 骨のびらんや変形（骨リモデリング）を示すことが報告さ れて抢り，この点は前頭洞病変と好酸球浸潤を考光る上で 興味深いものと言える ${ }^{14)}$ 。の骨リモデリングの発症機序 としては, 副鼻腔内に充満する膿汁・ムチンやポリープ粘 膜による物理的圧迫と同時に，持続する好酸球性炎症の波 及の可能性も指摘されている ${ }^{15)}$ 。また部位としては, 眼窩 壁を取り囲む前頭洞の骨壁などが多いとされて抢り ${ }^{16)}$, 前 頭洞病変を考える上でもその機序の解明が待ち望まれる。

\section{終わりにあたって}

化膿性（非好酸球性）副鼻腔炎治療の主体であるマクロ ライドと粘液調整剂の併用療法は, 罹患した副鼻腔各洞粘 膜の粘液線毛輸送機能の回復・調整作用に主目的が置かれ ていた。これに対して, 好酸球性副鼻腔炎に扔ける薬物治 療は, 粘膜病変の主因である好酸球浸潤を直接標的とした もの，すなわちステロイド製剤が主役を担っている。また， 手術時には鼻中隔矯正術や粘膜下下鼻甲介骨切除術を積極 的に併用し，鼻副鼻腔形態を改善することは好酸球性副鼻 腔炎治療の第一歩といえる。しかしながら今回，概説した ように解剖学的危険部位が近接しており，手技的にも難易 度の高い前頭洞手術は他の副鼻腔に比較して狭小なドレ ナージルートしか得られないことも多い。従って薬物療法 に加えて, 術後には内視鏡を用いた詳細な前頭陥凹の視
診, 丁寧な鼻汁と痂皮除去, 自宅での鼻洗浄指導など総合 的な対処が重要であると思われる。

本論文に関して, 開示すべき利益相反状態は存在しない。

\section{文献}

1) 藤枝重治, 坂下雅文, 他. 好酸球性副鼻腔炎の診断基準： JESREC Study，好酸球性副鼻腔炎 (JESREC Study).アレル ギー 2015; 64(1): 38-45.

2) Lee WT, Kuhn FA, et al. 3D computed tomographic analysis of frontal recess anatomy in patients without frontal sinusitis. Otolaryngol Head Neck Surg. 2004; 131(3): 164-73.

3) Kubota K, Takeno S, et al. Frontal recess anatomy in Japanese subjects and its effect on the development of frontal sinusitis: computed tomography analysis. J Otolaryngol Head Neck Surg. 2015; 44: 21.

4) Wormald PJ. Anatomy of the frontal recess and frontal sinus with three-dimentional reconstruction. Endoscopic Sinus Surgery. Anatomy, Three-Dimensional Reconstruction and Surgical Technique, 3rd ed. New York: Thieme; 2013. p. 45-80.

5) 鴻 信義. 内視鏡下鼻内副鼻腔手術における前頭洞開放の要 点. 日耳鼻 2013; 116(11): 1250-1.

6) Takeno S, Hirakawa K, et al. Pathological mechanisms and clinical features of eosinophilic chronic rhinosinusitis in the Japanese population. Allergol Int. 2010; 59(3): 247-56.

7) 岡田昌浩, 中村光士郎, 他. 内視鏡下鼻内副鼻腔手術におけ る前頭洞の開放一当科に抢ける方法と術後成績一. 日鼻誌 2007; 46(4): 301-6.

8) Okushi T, Mori E, et al. Impact of residual ethmoid cells on postoperative course after endoscopic sinus surgery for chronic rhinosinusitis. Auris Nasus Larynx 2012; 39(5): 484-9.

9) Adapinar B, Kurt E, et al. Computed tomography evaluation of paranasal sinuses in asthma: is there a tendency of particular site involvement? Allergy Asthma Proc. 2006; 27(6): 504-9.

10) Snidvongs $K$, Chin D, et al. Eosinophilic rhinosinusitis is not a disease of ostiomeatal occlusion. Laryngoscope. 2013; 123(5): 1070-4.

11) Chan Y, Melroy CT, et al. Long-term frontal sinus patency after endoscopic frontal sinusotomy. Laryngoscope. 2009; 119(6): 1229-32.

12) Bassiouni A, Wormald PJ. Role of frontal sinus surgery in nasal polyp recurrence. Laryngoscope. 2013; 123(1): 36-41.

13）久保田和法, 竹野幸夫, 他. 好酸球性副鼻腔炎症例における 前頭陥凹粘膜のサイトカイン発現の特徵. 日耳鼻 2013; 116(4): 548.

14) 花牟禮豊, 高木 実, 他. 前頭蓋底・眼窩側への著明な進展 を示したアレルギー性真菌性鼻副鼻腔炎症例。日鼻誌 2013; 52(1): 36-42.

15) Nussenbaum B, Marple BF, et al. Characteristics of bony erosion in allergic fungal sinusitis. Otolaryngol Head Neck Surg. 2001; 124(2): 150-4.

16) Wise SK, Rogers GA, et al. Radiologic staging system for allergic fungal rhinosinusitis (AFRS). Otolaryngol Head Neck Surg. 2009; 140(5): 735-40. 